PLEASE NOTE! THIS IS PARALLEL PUBLISHED VERSION OF THE ORIGINAL ARTICLE

To cite this Article: M. Ferruzca, P. Tossavainen, V. Kaartti, T. Santonen (2016) A COMPARATIVE STUDY OF SERVICE DESIGN PROGRAMS IN HIGHER EDUCATION, INTED2016 Proceedings, pp. 6490-6498.

DOI: $10.21125 /$ inted.2016.0531 


\title{
A COMPARATIVE STUDY OF SERVICE DESIGN PROGRAMS IN HIGHER EDUCATION
}

\author{
Marco Ferruzca $^{1^{*}}$, Päivi J. Tossavainen ${ }^{2}$, Virpi Kaartti ${ }^{2}$, Teemu Santonen ${ }^{2}$ \\ ${ }^{1}$ Universidad Autónoma Metropolitana (MEXICO) \\ ${ }^{2}$ Laurea University of Applied Sciences (FINLAND)
}

\begin{abstract}
Service design has gained increasingly attention during the last years. It has been approached from the design, business, engineering and the computer science perspectives. Furthermore, service design has grown considerable as an economic activity. Through, conferences, new journals, and magazines about service design, the topic can be easily found. Albeit it is not fully defined, it has becoming an interesting area to explore. At the same time, service design programs have emerged into higher education, oriented to prepare future professionals with new competences. This includes skills to be capable to guide innovation by fostering the co-creation of value with users and to design the best experiences with customers alongside with generating a good return on their investment. If we take it for granted that service design faces challenges in moving forward as a discipline, we need to consider the contextual, social or technological perspective to understand it. The purpose of the paper is to explore how well the service design is embedded in the higher education. Covering Top 50 universities, in which 13 meet our selection criteria, offer 30 service design programs which have been explored to provide an international comparative study based on the type of the program and its curriculum content. The higher education focus is reflected, because we consider that those educated in service design are in future important actors to foster innovation in both private and public organizations.
\end{abstract}

Keywords: higher education, service design, adaptive innovators, innovation capabilities.

\section{INTRODUCTION}

The growth of service sector and transition to service-based economies has impacts on all levels in society. As service business has grown considerable as an economic activity, new professions are emerging. Thus, we need to understand it better. Service-oriented research has brought a wide variety of knew knowledge and theoretical proposals. It has acquired its place in marketing and management literature. While it is an evolving discipline, many programs remain on conceptual level. Innovation capability, development skills, and productivity knowledge have become a global challenge.

As with any industry, also education sector need to apply novel business practices. Despite the growing interest in service design, it is still an emerging field from the educational point of view. Thus, the purpose of this paper is to increase the knowledge of applying service design in the context of higher education. Recommended is that higher education institutes (HEI) should "enable graduates from various disciplines to become T-shaped professionals or adaptive innovators" [1] [2]. There seems to be a need for service designers albeit the profession nor the education is not yet fully defined. Despite the vivid discussion (see for example [3] [4]), the lack of universally accepted definition for the term 'service' to start with means that even scholars define it differently [5]. Tossavainen argues that capabilities related to service development and service innovation are not necessarily evolved in firms and the lack of needed know-how has slowed down service research impacts in society [6].

Géczy et al [7] suggest that universities should educate new professionals with service-oriented mindset. Similarly, Ostrom et al [8] call for wider collaboration across diverse stakeholders and approaches that combine the real-world with the theory of generating new knowledge. Students - on both Bachelor and Master level - focus on solving complex problems and challenges with different skills and thus teachers need to use and educate these skills in classrooms [9].

"Visiting scholar at Laurea University of Applied Sciences (2015-2016). 
As service design has become a central framework within industry to innovate service, it has contributed to higher education: new programs have been established around the topic. However, there is little analysis of the content of those programs. We conducted a search in academic journals for this kind of studies but we didn't find any published in the last five years (2011-2015). This paper aims to fulfil that gap in research by providing a comparative study of service design programs in higher education.

The objective of this article is to present an overview of service design education through a comparative study of several international service design programs. This review allows to identify common topics of programs and also some emerging trends.

\section{CONCEPTUALIZING SERVICE DESIGN EDUCATION}

Service design has attracted wide publicity in both business and academia. Since the introduction of the concept in 1990s to modernize the design education [10], service design concept has been researched and revisited from the design, business, engineering or the computer science perspective. The transition to service-based economies, the application of service-oriented research in developing service business, calls for the business orientation to be included in the service design concept. Service business and service offering development need to be approached theoretically from the service marketing and management point of view. Thus, the interdisciplinary nature of services calls for combination of service design with service business, strategy and management [11]. In business context, this may also require integration of various resources i.e. stakeholders with differing orientation through multi-party collaboration [12].

Service development competences are distinctive competences, which rely on service theories (knowledge) and their implications in practice [7] [8]. Tossavainen and Kaartti propose that in business education, service design could be seen as a vehicle to enhance innovativeness through visualization of the holistic service development process [13].

The service development skills include variety of methods, models, techniques, and tools that have originated in the past decades in different academic fields. Service design can be seen as a part of service development. Therefore, understanding the practices, methods and tools for service development and service design is essential. While the theoretical foundation for service business can be found in service marketing and management literature, the service design stems from design thinking approach that incorporates relevant methods and tools. This dichotomy of theory and practice is conceptualized as the service capability framework [6].

Service design can be viewed as applying design methods and principles to the design of services [14]. Wetter-Edman described the service design through specific schools of thought from interface design, to experience design, to interdisciplinary such as service marketing and management issues [15]. Thus, service design is complementary to conventional service development approaches. Despite the ongoing research, service design is still a new discipline and evolving. Furthermore, it is a field of practice originating from design thinking, and therefore, service design or design of service takes the disciplinary role and design for service looks into what design can bring to service [16].

Recently, service design programs have emerged into higher education. Universities and other higher education institutes around the world have included service design programs as part of their education portfolio. Undergraduate and graduate programs have been created to offer a service design education, which aims to prepare future professionals with new competences. The drivers for the curriculum design varies and may originate from the design, business, engineering and the computer science perspective.

In order to achieve the multidisciplinary knowledge applied in service innovation and design through the advanced study of different service theories and their implications for service innovation and design practice [17], this paper reposition and redefines the service design education to be based on understanding the multidisciplinary approach required. This includes the competences and skills to be capable to guide systematically innovation by fostering the co-creation of value with users and to design the best experiences with customers alongside with generating a good return on their investment. 
Service design faces challenges in moving forward as a discipline and profession. Respectively, differing viewpoints exists how it is educated in various HEI. To understand this situation better, what is the status of the service design education?

\section{RESEARCH DESIGN CONSIDERATIONS}

\subsection{Definition of research question}

The research questions for the study are:

1 What is the actual higher education offer of service design programs?

2 What are the main themes of the content?

3 Are they developed based on similar approaches?

\subsection{Sources of Information}

For this purpose, information about service design programs was searched on Internet based the first fifty universities were considered. Three sources were used to gather information:

a) The top 50 universities from the Times Higher Education World University Rankings 2015-2016 [18]. Instead of using a public web search engine, a filter like this ranking allows identifying, from an academic point of view, those service design programs offered leading universities.

b) The web site for each of the 50 universities to identify service design programs.

c) The service design program description; curriculum was reviewed.

It is important to emphasise that only 13 out of 50 universities meet the criteria of offering a service design program in their educational portfolio. These programs represent the unit of analysis, which later on the paper are analysed more in-depth curriculum level.

\subsection{Construction of measures}

In order to analyse the information provided in the net pages of the programs in selected universities, two matrix were developed. The first matrix contains general information to identify each program while the second is focused on curriculum content.

\subsubsection{Matrix 1: Service design programs}

A set of features was defined to distinguish service design programs. The features were: program name, description, program type, orientation to service design, university, country, ranking position, and expertise. Regarding program type, it specifies if service design program is offered as: a) executive education, b) undergraduate education or c) graduate education. The "orientation to service design" feature was defined to identify if the program type is completely focused on service design or if it is just a complement of a wide education program. Finally, "expertise" was useful to identify the institution experience in certain domain: business, design or technology.

\subsubsection{Matrix 2: Comparative service design curriculum}

In order to compare curriculum content and basis a set of themes was also defined. The nature of the multidisciplinary knowledge and the competences that combine academic rigour with managerial relevance were sought after. In search of the conceptual framework that could be used in the analysis, only one that was based on extensive research could be found [17]. The education need to respond to the demand of the competences service designers and developers would need [19]. Two competences were respectively defined and they were used in this study as themes to review the contents of each identified service design program. These competences are 1) business competences in service innovation and 2) service design competences. Each of them has underlying properties (see the table 1). 
Table 1. Categorization of competences for service design curriculum

\begin{tabular}{|l|l|l|}
\hline Competence & \multicolumn{1}{|c|}{ Area of expertise } & \multicolumn{1}{c|}{ Key contents } \\
\hline $\begin{array}{l}\text { Business } \\
\text { competence in } \begin{array}{l}\text { service } \\
\text { innovation }\end{array}\end{array}$ & $\begin{array}{l}\text { Developing insights into a } \\
\text { business, its customers, } \\
\text { business environment and } \\
\text { future trends }\end{array}$ & futures thinking, analysis of global environment \\
\cline { 2 - 3 } & $\begin{array}{l}\text { Managing the service } \\
\text { business }\end{array}$ & $\begin{array}{l}\text { Management of networks, service accounting and } \\
\text { management control systems, development of } \\
\text { revenue models, productivity, investments and } \\
\text { financial issues, pricing of services, marketing and } \\
\text { selling of services, intrapreneurship }\end{array}$ \\
\cline { 2 - 4 } & $\begin{array}{l}\text { Fostering the service } \\
\text { culture and service } \\
\text { leadership }\end{array}$ & $\begin{array}{l}\text { Change leadership, service culture, empowerment of } \\
\text { personnel }\end{array}$ \\
\hline service design \\
competence & $\begin{array}{l}\text { Creating innovative value } \\
\text { propositions }\end{array}$ & $\begin{array}{l}\text { Value co-creation (co-design and co-production), } \\
\text { new service development, design of service concept, } \\
\text { design of service resources, design of service } \\
\text { delivery and service process, use of technology in } \\
\text { service processes }\end{array}$ \\
\cline { 2 - 4 } & $\begin{array}{l}\text { User-centric service } \\
\text { design }\end{array}$ & $\begin{array}{l}\text { Design thinking, customer experiences and value } \\
\text { creation, integration of customers in new service } \\
\text { development processes, customer processes, } \\
\text { customer interactions and touchpoints, deeply } \\
\text { knowing the customers/end-users, service design } \\
\text { process and methods (technique and tools) }\end{array}$ \\
\hline
\end{tabular}

This categorization is influenced by an interpretativist approach to explore the current themes under study. The key content list provides an illustration of the variety of themes and is not intend to be comprehensive.

\subsection{Analysis of the collected data}

In order to answer the research questions, the first exploratory review has been conducted.

For this purpose, we executed a desktop research. Service design programs were approached from two directions. First of all, analysis was carried out whether the top universities has included service design program. For the purpose of this paper, 50 best global universities from the Times Higher Education World University Rankings 2015-2016 were selected. Assumed is that the best universities are forerunners in establishing new programs. Moreover, 30 curriculum designs have been assessed to provide an international comparative study. Service design programs are reviewed to provide an overview of the current state of the service design education.

\subsubsection{Service design programs}

To show the variety of programs, Table 2 summarizes the information available. Only some universities within the best fifty propose one or more programs. The names of identified programs are not provided, only the university name. Orientation and approach information is added to the list. If there are several courses in the same university, there is also several lines within the university. 
Table 2. Service design programs

\begin{tabular}{|c|c|c|c|c|c|}
\hline $\begin{array}{c}\# \\
\text { Program }\end{array}$ & University & Ranking & $\begin{array}{l}\text { Program type } \\
\text { (E= Executive } \\
\text { Education; } \\
\text { U=Undergraduate } \\
\text { Programs; } \\
\text { G=Graduate } \\
\text { Programs }\end{array}$ & $\begin{array}{c}\text { Orientation to } \\
\text { service design } \\
\text { ( } \mathrm{F}=\text { = Full Orientation; } \\
\mathrm{C}=\text { Complementary } \\
\text { orientation) }\end{array}$ & $\begin{array}{c}\text { Expertise approach is } \\
\text { based on } \\
\text { (B=Business; } \\
D=\text { Design; } \\
\text { T=Technology; } \\
\text { I=Information) }\end{array}$ \\
\hline 1 & \multirow{3}{*}{$\begin{array}{l}\text { Stanford } \\
\text { University }\end{array}$} & \multirow{3}{*}{3} & $G$ & $C$ & $D \& T$ \\
\hline 2 & & & $\mathrm{G}$ & $\mathrm{C}$ & D \\
\hline 3 & & & $\mathrm{G}$ & C & $\mathrm{B}$ \\
\hline 4 & \multirow{5}{*}{$\begin{array}{l}\text { University of } \\
\text { Cambridge }\end{array}$} & \multirow{5}{*}{4} & E & $\mathrm{F}$ & B \\
\hline 5 & & & $\mathrm{E}$ & $\mathrm{F}$ & $\mathrm{B}$ \\
\hline 6 & & & $\mathrm{G}$ & $C$ & $\mathrm{~T}$ \\
\hline 7 & & & $\mathrm{E}$ & $\mathrm{F}$ & $\mathrm{B}$ \\
\hline 8 & & & $\mathrm{G}$ & C & $B$ \\
\hline 9 & MIT & 5 & $\mathrm{E}$ & C & $\mathrm{B}$ \\
\hline 10 & $\begin{array}{l}\text { Harvard } \\
\text { University }\end{array}$ & 6 & $E$ & $F$ & B \\
\hline 11 & \multirow{2}{*}{$\begin{array}{c}\text { University of } \\
\text { California, } \\
\text { Berkeley }\end{array}$} & \multirow{2}{*}{13} & $U$ & C & 1 \\
\hline 12 & & & $U$ & C & 1 \\
\hline 13 & \multirow{2}{*}{$\begin{array}{l}\text { Cornell } \\
\text { University }\end{array}$} & \multirow{2}{*}{18} & $\mathrm{E}$ & $\mathrm{F}$ & $\mathrm{T}$ \\
\hline 14 & & & G & C & $\mathrm{T}$ \\
\hline 15 & $\begin{array}{l}\text { University of } \\
\text { Toronto }\end{array}$ & 19 & G & C & 1 \\
\hline 16 & \multirow{8}{*}{$\begin{array}{l}\text { Carnegie } \\
\text { Mellon } \\
\text { University }\end{array}$} & \multirow{8}{*}{22} & $U$ & $C$ & $\mathrm{D}$ \\
\hline 17 & & & $U$ & C & $\mathrm{D}$ \\
\hline 18 & & & $\mathrm{G}$ & $\mathrm{C}$ & $\mathrm{D}$ \\
\hline 19 & & & $U$ & $\mathrm{C}$ & $B \& T$ \\
\hline 20 & & & G & $C$ & $\mathrm{~T}$ \\
\hline 21 & & & $\mathrm{G}$ & C & $\mathrm{T}$ \\
\hline 22 & & & $U$ & C & $\mathrm{T}$ \\
\hline 23 & & & $U$ & C & \\
\hline 24 & $\begin{array}{l}\text { London } \\
\text { School of } \\
\text { Economics } \\
\text { and Political } \\
\text { Science }\end{array}$ & 23 & G & C & B \\
\hline 25 & \multirow{2}{*}{$\begin{array}{l}\text { University of } \\
\text { Edinburgh }\end{array}$} & \multirow{2}{*}{24} & $U$ & $C$ & B \\
\hline 26 & & & G & C & $\mathrm{B}$ \\
\hline 27 & \multirow{2}{*}{$\begin{array}{l}\text { Northwestern } \\
\text { University }\end{array}$} & \multirow{2}{*}{25} & $U$ & C & $\mathrm{D}$ \\
\hline 28 & & & G & C & $B \& D$ \\
\hline 29 & $\begin{array}{c}\text { Karolinska } \\
\text { Institute }\end{array}$ & 28 & U & C & B \\
\hline 30 & $\begin{array}{l}\text { University of } \\
\text { Honk Kong }\end{array}$ & 44 & $E$ & $\mathrm{~F}$ & B \\
\hline
\end{tabular}




\subsubsection{Comparative service design curriculum}

In order to compare the curriculum in the thirty service design programs in the table above, the themes were examined. During the examination, others topics were included in three service design programs: rapid prototype engineering, mining collective intelligence, conflict resolution and influence without authority.

Table 3. The themes identified within the programs

\begin{tabular}{|c|c|c|c|c|c|}
\hline \multirow[b]{2}{*}{$\begin{array}{c}\text { ID } \\
\text { Program }\end{array}$} & \multicolumn{3}{|c|}{ Business management and leadership competences } & \multicolumn{2}{|c|}{$\begin{array}{c}\text { Value creation and service } \\
\text { design }\end{array}$} \\
\hline & $\begin{array}{c}\text { Developing insights into a } \\
\text { business, its customers, } \\
\text { business environment and } \\
\text { future trends }\end{array}$ & $\begin{array}{l}\text { Managing the } \\
\text { service } \\
\text { business }\end{array}$ & $\begin{array}{l}\text { Fostering the } \\
\text { service culture } \\
\text { and service } \\
\text { leadership }\end{array}$ & $\begin{array}{c}\text { Creating } \\
\text { innovative value } \\
\text { propositions }\end{array}$ & $\begin{array}{l}\text { User- } \\
\text { centric } \\
\text { service } \\
\text { design }\end{array}$ \\
\hline 1 & & & & $x$ & $x$ \\
\hline 2 & & & & & $x$ \\
\hline 3 & $x$ & $x$ & & & $x$ \\
\hline 4 & & & & $x$ & $x$ \\
\hline 5 & $x$ & $X$ & $x$ & & \\
\hline 6 & & $x$ & & & \\
\hline 7 & $x$ & $x$ & $x$ & & \\
\hline 8 & $x$ & $x$ & $x$ & & \\
\hline 9 & & $x$ & & & \\
\hline 10 & $x$ & $x$ & $x$ & $x$ & $x$ \\
\hline 11 & & & & & $x$ \\
\hline 12 & & & & & $x$ \\
\hline 13 & & & & & $x$ \\
\hline 14 & & $x$ & $x$ & & $x$ \\
\hline 15 & & $x$ & & & \\
\hline 16 & & & & $x$ & \\
\hline 17 & & & & $x$ & \\
\hline 18 & & & & $x$ & \\
\hline 19 & & $\mathrm{X}$ & & & \\
\hline 20 & & & & $x$ & \\
\hline 21 & & & & $x$ & $x$ \\
\hline 22 & & & & $x$ & \\
\hline 23 & & & & $x$ & \\
\hline 24 & & & & $x$ & \\
\hline 25 & & & & & $X$ \\
\hline 26 & & $x$ & & $x$ & \\
\hline 27 & & & & $x$ & \\
\hline 28 & $x$ & $x$ & $x$ & $x$ & $x$ \\
\hline 29 & & $x$ & & $x$ & \\
\hline 30 & & $x$ & & $x$ & \\
\hline TOTAL & 6 & 14 & 6 & 16 & 12 \\
\hline
\end{tabular}

As this examination is based solely on the information available in the internet, it may be incomprehensive.

\section{FINDINGS}

This paper has examined service design as an emerging field in higher education. Firstly, the paper positioned service design education to be linked with a proper theoretical viewpoint. In developing service business and/ or service offering the theoretical view needs to be that of service marketing and management. Secondly, the paper has examined service design as part of service development positioning it with a wider context. Furthermore, the complementary nature of service design methods, 
techniques and tools to service development was defined. Thirdly, the paper has developed two measures to examine service design programs. These measures are Matrix 1 service design educational offering type to identify the type of education i.e. executive, undergraduate, and graduate offered. Only those type of programs were considered. Matrix 2 identifies themes to analyse the basis of the service design curriculums.

The exploratory review of top 50 universities revealed that 13 of them offer 30 programs to approach to service design. 7 are offered as executive programs, 10 are related to undergraduate programs and 13 are part of graduate programs. Based on the last two types of programs, service design knowledge is embedded in wide educational programs but there are not undergraduate and graduate programs completely focused in service design. There are only 6 executive options focused completely in service design. Among the 13 universities identified, 7 of them are in the USA and they actually offer 19 programs about service design; 3 are in the United Kingdom and they offer 8 different options; then Canada, Honk Kong and Sweden offer one program each one. Regarding the "expertise approach", 11 programs are offered by universities with business experience, 7 with technology experience and 6 with design experience. 3 of the programs are offered by schools in the field of information and knowledge management. Finally, also 3 programs are offered within a graduate program supported by two institutions with different experience. Table 2 summarizes findings in relation to service design curriculum contents. The names of identified programs are not provided, only the university hosting them. According to the assessment, 16 programs offer a curriculum which includes topics about creative innovative value propositions; 14 include topics about managing the service business; 12 are related to user-centric service design themes. The rest of areas of expertise are rarely considered in curriculum. Only 2 service design programs seem to cover all the areas of expertise services designers and developers need.

\section{CONCLUSIONS}

Educating future professionals with necessary service business mindset and managerial understanding, and the learning to use of service development and design methods are crucial in service knowledge transition to companies and organizations. Business practitioners, designers and non-designers can cultivate their service business development capabilities in multiple ways; higher education programs are just one avenue to pursue.

To execute a comparative analysis of the service design programs provided by the top universities proved to be a challenge. This is because many universities do not specify all necessary information to analyse the programs. However, using the Times Higher Education World University Rankings 2015-2016 is a good path to identify leading universities offering service design education.

In order to provide in depth analysis two matrixes were created. The first one was based on some general characteristics to describe the service design programs. The second one was based on some competences for service design proposed in the SID program at Laurea University of Applied Sciences.

The findings of this study indicate that some of the fifty best global universities (26\%) offer a service design program. Most of them are part of master's degree programs in several domains like design, business, information systems, information and knowledge management, manufacturing and human computer interaction. Just a few programs are completely focused in service design. This was the case of executive programs.

Besides, universities with business expertise seems the main educational agents offering service design education, opposite to design schools. In the future it would be interesting to compare how each institution approach to common topics like co-design, co-production or customer interaction, just to mention some examples.

It is important to highlight that three information schools are identified offering a multidisciplinary approach to service design. Also, three programs are offered in partnership with institutions having different expertise. Once the programs have been recognized, the people in charge and staff can be contacted with the aim to work in a deeper understanding of curriculum.

In the future, others sources of information can be considered to try to understand the current state of service design education by region. It would be also interesting to identify what is the impact of service design education in the service industry of selected economies like developing countries. Albeit the 
ever increasing discussion, we need more evidence, information, and experiences of service design approaches in higher education.

\section{REFERENCES}

[1] Bishop, Kevin, Bolan, Greg, Bowen, David, Steve. (2008). Succeeding through service innovation: a service perspective for education, research, business and government. University of Cambridge.

[2] Spohrer, J. C., Gregory, M. and Ren, G. (2010). The Cambridge-IBM SSME white paper revisited. In Maglio et al. (eds) (2010). Handbook of Service Science, service science: research and Innovations in the Service Economy. pp. 677-706

[3] Gronroos, C. (2006). Adopting a service logic for marketing. Marketing Theory, 6(3), 317-333. doi:10.1177/1470593106066794

[4] Lusch, R. F., \& Vargo, S. L. (2006). The service-dominant logic of marketing: Dialog, debate, and directions. Armonk, NY: M.E. Sharpe.

[5] Edvardsson, B., Gustafsson, A., \& Roos, I. (2005). Service portraits in service research: a critical review. Int J of Service Industry Mgmt, 16(1), 107-121. doi:10.1108/09564230510587177

[6] Tossavainen, Päivi J. (2012). The Service capabilities: Steps to Service Designed Business. Innovative Service Perspectives. Proceedings from the AMA SERVSIG International Service Research Conference, Hanken School of Economics, Helsinki, Finland, June 7-9, 2012. ISBN 978-952-232-170-1, http://hdl.handle.net/10138/36614, p. 87

[7] Géczy, P., Izumi, N. and Hasida, K. (2010) Service Science, Quo Vadis? International Journal of Service Science, management, Engineering and Technology, 1(1), pp.1-16

[8] Ostrom, A. L., Bitner, M. J., Brown, S. W., Burkhard, K. A. , Goul, M. , Smith-Daniels, V., Demirkan, H. and Rabinovich, E. (2010). Moving Forward and Making a Difference: Research Priorities for the Science of Service. Journal of Service Research, pp.1-33

[9] Ostrom, A. L., Bitner, M. J., Brown, S. W., Burkhard, K. A. , Goul, M. , Smith-Daniels, V., Demirkan, H. and Rabinovich, E. (2010). Moving Forward and Making a Difference: Research Priorities for the Science of Service. Journal of Service Research, pp.1-33

[10] Grönroos, C. (2007). Service management and marketing: Customer management in service competition. Chichester, West Sussex: J. Wiley \& Sons.

[11] Mager, B. (2009). Service design as an emerging field in Miettinen S. And Koivisto, M. (Eds). Designing Services with Innovative Methods. University of Art and Design Helsinki, B93, pp.267

[12] Ojasalo, K. and Ojasalo, J. (2009). Developing service design education. in Miettinen S. And Koivisto, M. (Eds). Designing Services with Innovative Methods. University of Art and Design Helsinki, B93, pp.267

[13] Tossavainen, P. J. (2013). Beyond sporadic actions: How to approach multi-party stakeholder collaboration in service development Journal of Business Market Management, 6(4):171-191

[14] Tossavainen, Päivi J.\& Kaartti, Virpi (2015). Don't the cobbler's children have shoes? A Service Design Lens And Visualization Tools In Action In Higher Education. 5th International Conference on Education, Research and Innovation, ICERI 2015 Conference, September 2425, 2015 Rio de Janeiro, Brazil.

[15] Holmlid, S. and Evenson, S. (2008). Bringing Service Design to Service Sciences, Management and Engineering. In Hefley and Murphy (2008) Service Science, Management and Engineering Education for the 21st. Service Science: Research and Innovations in the Service Economy, pp. 341-345.

[16] Wetter-Edman, K. (2014). Design for Service. A framework for articulating designers' contribution as interpreter of users' experience. PhD Dissertation, the University of Gothenburg, Sweden. 248 pages

[17] Meroni, A. and Sangiorgi, D. (2011). Design for services. Gower Publishing, Farnham, UK. 2722 pages 
[18] Ojasalo, J. and Ojasalo, K. (2012) Creating Competences in Service Innovation and Design. The SID Master's Programme for Practitioners Combines Business and Design Competences. Touchpoint 3, 3. pp.58-59

[19] World University Rankings 2015-2016: Institutional data collection under way. (1989, December 31). Retrieved January 19, 2016, from https://www.timeshighereducation.co.uk/world-universityrankings/news/world-university-rankings-2015-2016-institutional-data-collection-underway

[20] Laurea (2016). Curriculum master of business administration service innovation and design.www.Laurea.fi. https://www.laurea.fi/en/studying-and-applying/masters-programmes-inenglish/service-innovation-and-design accessed on 20 Jan 2016. 